\title{
Rituximab Therapy in Adults with Refractory Symptomatic Immune Thrombocytopenia: Long-Term Follow-Up of 15 Cases
}

\author{
Refrakter Semptomatik Immün Trombositopeni Tanılı Erişkinlerde Rituksimab Tedavisi: \\ 15 Olgunun Uzun Süreli İlemi
}

Fehmi Hindilerden¹, İpek Yönal-Hindilerden², Mustafa Nuri Yenerel², Meliha Nalçacl², Reyhan Diz-Küçükkaya³

${ }^{1}$ Bakırköy Sadi Konuk Training and Research Hospital, Clinic of Hematology, Istanbul, Turkey

2istanbul University Istanbul Faculty of Medicine, Department of Internal Medicine, Division of Hematology, Istanbul, Turkey

3istanbul Bilim University Faculty of Medicine, Department of Internal Medicine, Division of Hematology, Istanbul, Turkey

\section{Abstract}

Objective: This paper prospectively evaluates the long-term followup [mean \pm standard deviation (SD) duration: $89.7 \pm 19.4$ months] data of 15 patients ( 13 females and 2 males) with refractory symptomatic immune thrombocytopenia (ITP) treated with rituximab.

Materials and Methods: Rituximab was administered at $375 \mathrm{mg} / \mathrm{m} 2$ weekly for a total of 4 doses. Complete response (CR) was defined as a platelet count of $\geq 100,000 / \mathrm{mm}^{3}$ and partial response (PR) as a platelet count of $\geq 30,000 / \mathrm{mm}^{3}$ but less than $100,000 / \mathrm{mm}^{3}$. Early response (ER) and late response (LR) were defined as response within 42 days and after 42 days of initiation of rituximab therapy, respectively. Sustained response (SR) was defined as response lasting for at least 6 months.

Results: Mean age $( \pm S D)$ at the start of rituximab was $46.6 \pm 11.3$ years. Mean platelet count $( \pm \mathrm{SD})$ prior to rituximab treatment was $17,400 \pm 8878 / \mathrm{mm}^{3}$. The mean time $( \pm \mathrm{SD})$ between rituximab therapy and response to rituximab in early responders and late responders was $1.8 \pm 1.3$ weeks and $10 \pm 2.8$ weeks, respectively. Mean durations $( \pm S D)$ of $E R$ and $L R$ were $51 \pm 47.2$ months and $6 \pm 4.2$ months, respectively. Seven of the 15 patients (46.7\%) showed an initial response to rituximab (5 ER and $2 \mathrm{LR}$ ). The rate of SR over 6 months was $26.7 \%$ (4/15). Among the responders to rituximab, $3(3 / 7,42.9 \%)$ maintained their response 1 year after rituximab treatment and $2(2 / 7,28.6 \%)$ had ongoing response 5 years after initiation of rituximab. Two of the 7 patients (28.6\%) still maintained their response 98 months after initiation of rituximab. All 5 initial responders with subsequent relapse achieved response from subsequent treatment modalities (3 CR, 2 PR).

Conclusion: Our data confirm, over a long period of observation, that rituximab is safe and effective in the management of patients with chronic refractory primary ITP.

Keywords: Immune thrombocytopenia, Rituximab, Early response, Late response, Sustained response

\section{Öz}

Amaç: Çalışmamızda rituksimab ile tedavi edilen refrakter semptomatik immün trombositopeni (ITP) tanılı 15 olgunun (13 kadın ve 2 erkek) uzun süreli izlemi sonucundaki [ortalama \pm SD (standart deviasyon) süresi: 89,7 $\pm 19,4$ ay] verileri incelenmiştir.

Gereç ve Yöntemler: Rituksimab haftada bir 375 mg/m2 dozunda toplam 4 doz uygulanmıştır. Tam yanıt (TY) trombosit sayısının $\geq 100,000 / \mathrm{mm}^{3}$ olması ve parsiyel yanıt (PY) trombosit sayısının $\geq 30,000 / \mathrm{mm}^{3}$ olması fakat $100,000 / \mathrm{mm}^{3}$ ün altında olması olarak tanımlanmıştır. Erken yanıt (EY) ve geç yanıt (GY) ise sırasıyla rituksimab başlangıcından 42 gün içinde ve 42 gün sonra yanıt elde edilmesi olarak tanımlanmıştır. Sürekli yanıt (SY), yanıtın en az 6 ay sürmesi olarak tanımlanmıştır.

Bulgular: Rituksimab tedavisinin başladığı sırada ortalama yaş $( \pm S D)$ $46,6 \pm 11,3$ yıldır. Rituksimab tedavisi öncesinde ortalama trombosit sayısı $\left( \pm\right.$ SD) $17,400 \pm 8878 / \mathrm{mm}^{3}$ dür. Erken ve geç yanıt edilen olgularda rituksimab başlangıcı ile yanıta kadar geçen ortalama süre $( \pm$ SD) sırasıyla $1,8 \pm 1,3$ hafta ve $10 \pm 2,8$ hafta olarak saptanmıştır. EY ve GY elde edilen olgularda ortalama yanıt süresi sırasıyla $51 \pm 47,2$ ay ve $6 \pm 4,2$ aydır. On beş olgunun 7 'sinde $(\% 46,7)$ rituximab tedavisine başlangıçta yanıt elde edilmiştir (5 EY, 2 GY). SY oranı \%26,7'dir (4/15). Rituksimab tedavisine yanıt veren olgular arasında 3 'ü $(3 / 7, \% 42,9)$ yanıtını bir yıldan fazla ve 2'si $(2 / 7, \% 28,6)$ yanıtını 5 yıldan fazla sürdürmüştür. Yedi olgunun ikisi $(\% 28,6)$ rituksimab başlangıcından 98 ay sonra halen yanıtını korumaktadır. Başlangıçta yanıt veren 5 olgunun hepsi relaps sonrasında ardışık tedavilere yanıt vermiştir (3 TY, 2 PY)

Sonuç: Çalışmamız uzun bir gözlem sonucunda kronik refrakter primer ITP olgusunda rituksimab tedavisinin güvenilir ve etkili olduğunu desteklemektedir.

Anahtar Sözcükler: İmmün trombositopeni, Rituksimab, Erken yanıt, Geç yanıt, Sürekli yanıt 


\section{Introduction}

Immune thrombocytopenia (ITP) is an autoantibody-mediated disorder characterized by a plateletcount of less than 100,000/ $\mathrm{mm}^{3}$ and increased risk of bleeding [1]. B cells play an important role in the pathophysiology of ITP, making B-cell depletion with rituximab a rational therapeutic option [2].

Glucocorticosteroids still remain the standard initial therapy for patients with symptomatic disease. Second-line treatment options include splenectomy, azathioprine, cyclosporine $A_{\text {, }}$ cyclophosphamide, danazol, mycophenolate mofetil, rituximab, and thrombopoietin-receptor (TPO-receptor) agonists [3]. In approximately $80 \%$ of patients, splenectomy results in response maintained at 10 years in 70\% of patients, but it is associated with a life long infection risk in 1\%-3\% of patients [4]. Chronic refractory ITP has been defined as failure to respond to splenectomy [5]. There is no standard of care for patients with refractory or relapsing ITP after splenectomy. Although spontaneous remissions may occur in some cases, these patients carry a significant risk of bleeding and have increased morbidity and mortality [5]. Further treatment is considered in chronic refractory ITP patients with low platelet counts and bleeding symptoms [5].

Over the last decades, rituximab has been widely used to treat primary ITP patients resistant to one or more treatment lines $[6,7,8,9,10,11,12,13,14,15]$. Rituximab is still used off-label as a second- or third-line option in many countries. Only a few systematic reviews on the efficacy of rituximab for adult ITP patients have been published $[6,16]$. In the meta-analysis by Arnold et al., overall response (OR) and complete response (CR) rates with rituximab were $62.5 \%$ and $46.2 \%$, respectively, with a median response duration of 10.5 months and a median followup of 9.5 months [6]. In a recent systematic review and metaanalysis including non-splenectomized ITP patients treated with rituximab, a CR rate of $46.8 \%$ was reported after a median follow-up of 6 months [16]. Khellaf et al. conducted a prospective multicenter registry of adult patients with ITP who were refractory to corticosteroids $(97 \%)$, IVIG (71\%), and splenectomy (10\%) and were treated with rituximab [17]. After a median follow-up of 24 months, 61\% showed an overall initial response and 39\% had sustained response (SR) [17]. Data on the long-term efficacy of rituximab in adult ITP are limited $[13,18,19,20,21]$. Several studies reported SR rates ranging from $21 \%$ to $40 \%$ after a median follow-up period ranging from 2 to 5 years $[13,18,19,20,21]$. Here we prospectively assess the overall initial response and SR rates to rituximab in 15 chronic refractory symptomatic ITP patients with a follow-up duration of 7 years.

\section{Materials and Methods}

We prospectively evaluated 15 patients (13 females and 2 males) diagnosed with chronic refractory ITP, all of whom had been treated with corticosteroids and splenectomy and received various immunosuppressive agents. Rituximab was offered to the sepatients as an off-label treatment following the approval of the Ministry of Health. Informed consent for study participation was obtained from all patients. Rituximab was administered intravenously at $375 \mathrm{mg} / \mathrm{m}^{2}$ once weekly for 4 weeks between November 2007 and March 2008. Selective spleen scintigraphy was performed to rule out accessory spleens. Baseline platelet count spriortoinitial administration of rituximab and before each weekly infusion were recorded. During the follow-upperiod, platelet counts were obtained at the $1^{\text {st }}, 3^{\text {rd }}, 6^{\text {th }}, 12^{\text {th }}, 18^{\text {th }}, 24^{\text {th }}, 32^{\text {td }}, 40^{\text {th }}, 48^{\text {th }}, 56^{\text {th }}, 64^{\text {th }}, 72^{\text {th }}, 80^{\text {th }}$, $88^{\text {th }}$, and $96^{\text {th }}$ months of rituximab therapy. CR was defined as any platelet count of at least $100,000 / \mathrm{mm}^{3}$ and the absence of bleeding, partial response (PR) as any platelet count between 30,000 and $100,000 / \mathrm{mm}^{3}$ and absence of bleeding, and no response (NR) as any platelet count lower than $30,000 / \mathrm{mm}^{3}$ or the presence of bleeding [1]. Early response (ER) was defined as a response within 42 days of rituximab infusion and late response (LR) was defined as response occurring 42 days after initiation of rituximab. OR to rituximab was the summation of ER and LR. SR was defined as response lasting for a minimum of 6 months [11,22]. Loss of response was defined as losing response to rituximab with any platelet count lower than $30,000 / \mathrm{mm}^{3}$ or the presence of bleeding and need for other therapy during follow-up. Time to response was defined as time from commencement of treatment to either CR or PR. Duration of response was defined as time from $C R$ or $P R$ until loss of $C R$ or PR.

\section{Statistical Analysis}

Data were processed using SPSS 21 (University of Sussex). Characteristics of patients were described with mean \pm standard deviation. Comparisons between groups were performed by chisquare test and Fisher's exact test. The analysis of continuous variables among the groups was performed using the MannWhitney $\mathrm{U}$ test. Odds ratios are accompanied by Cornfield 95\% confidence interval limits (Cls). A curve showing the proportion of patients with continuing response to rituximab was constructed by the Kaplan-Meier method. A general linear model for repeated measures was used to compare platelet values after the initiation of rituximab in responders vs. nonresponders. Probability values of $p<0.05$ were considered significant.

\section{Results}

Patient characteristics are summarized in Table 1. There was no response to initial corticosteroid treatment in 7 patients $(46.7 \%)$ and 8 patients (53.3\%) lost their response to corticosteroids during follow-up. All patients were already splenectomized before rituximab therapy but $5(33.3 \%)$ had an accessory spleen prior to rituximab infusion. The mean number of previous treatments 
Table 1. Characteristics of the patients.

Characteristics

Mean \pm SD

Number of patients

15

Sex

Female

Male

$13(86.7 \%)$

Age at diagnosis (years)

$2(13.3 \%)$

Age at the time of splenectomy (years)

$29.6 \pm 15.8$

Age at rituximab infusion (years)

Actual age (years)

Number of previous therapies

Previous therapies, $\mathrm{n}(\%)$

\section{Steroids}

Splenectomy

Azathioprine

Vincristine

IVIG

Other therapies

$31.7 \pm 16$

$46.6 \pm 11.3$

$54 \pm 11.6$

$3.6 \pm 1.04$

Accompanying diseases, $\mathrm{n}(\%)$

Diabetes mellitus

Hypertension

$15(100 \%)$

$15(100 \%)$

$11(73.3 \%)$

$5(33.3 \%)$

$2(13.3 \%)$

$5(33.3 \%)$

Response to initial corticosteroid treatment, n (\%)

NR

$\mathrm{R}$

$3(20 \%)$

$3(20 \%)$

Presence of accessory spleen before rituximab, $\mathrm{n}(\%)$

$5(33.3 \%)$

Initial response to rituximab therapy, $\mathrm{n}(\%)$

NR

ER

$8(53.3 \%)$

5 (33.3\%)

LR

$2(13.3 \%)$

Loss of response to rituximab, $\mathrm{n}(\%)$ $5 / 7(71.4 \%)$

SR to rituximab therapy, $\mathrm{n}(\%)$

$4(26.7 \%)$

Disease status at final observation, $\mathrm{n}(\%)$

CR

$\mathrm{PR}$

NR

Deceased

Platelet count at diagnosis $\left(/ \mathrm{mm}^{3}\right)$

Hemoglobin level at diagnosis $(\mathrm{g} / \mathrm{dL})$

WBC count at diagnosis $\left(/ \mathrm{mm}^{3}\right)$

Platelet count before rituximab treatment $\left(/ \mathrm{mm}^{3}\right)$

Platelet count at $1^{\text {st }}$ month after the initial dose of rituximab $\left(/ \mathrm{mm}^{3}\right)$

Time from diagnosis to splenectomy (months)

Time from splenectomy to rituximab therapy (months)

Time from diagnosis to rituximab therapy (months)

Time to response to rituximab of early responders (weeks)

$5(33.3 \%)$

$6(40 \%)$

$2(13.3 \%)$

$2(13.3 \%)$

$10100 \pm 4251$

$11.2 \pm 1.01$

$8513 \pm 2146$

$17,400 \pm 8878$

$68,733 \pm 95,213$

$24.6 \pm 19.3$

$179 \pm 103.8$

$204 \pm 106.2$

$1.8 \pm 1.3$

Time to response to rituximab of late responders (weeks)

$10 \pm 2.8$

Duration of ER (months)

$51 \pm 47.2$

Duration of LR (months)

$6 \pm 4.2$

Duration of OR (ER+LR) (months)

Follow-up period after rituximab treatment (months)

$38.1 \pm 44.4$

Death

$89.7 \pm 19.4$

$2(13.3 \%)$

NR: No response, R: response, ER: early response, LR: late response, SR: sustained response, CR: complete response, PR: partial response, OR: overall response, SD: standard deviation. 


\begin{tabular}{|c|c|c|c|c|c|c|c|c|c|}
\hline \multicolumn{10}{|c|}{ Early responders to rituximab therapy $(n=5)$} \\
\hline Number & Sex & $\begin{array}{l}\text { Actual } \\
\text { age }\end{array}$ & Previous therapies & $\prod_{\text {(weeks) }}^{\text {TRR }}$ & Relapse & $\begin{array}{l}\text { DOR } \\
\text { (months) }\end{array}$ & $\begin{array}{l}\text { FU period } \\
\text { after first } \\
\text { R therapy } \\
\text { (months) }\end{array}$ & $\begin{array}{l}\text { Treatment after } R \\
\text { therapy }\end{array}$ & $\begin{array}{l}\text { ITP final } \\
\text { status }\end{array}$ \\
\hline 1 & $\mathrm{~F}$ & 37 & $\begin{array}{l}\text { Steroids, } \\
\text { splenectomy }\end{array}$ & 4 & Yes & 52 & 98 & Steroids, IVIG & $\mathrm{CR}$ \\
\hline 2 & $\mathrm{~F}$ & 56 & $\begin{array}{l}\text { Steroids, } \\
\text { splenectomy, IVIG }\end{array}$ & 1 & No & 98 & 98 & No & $\mathrm{CR}$ \\
\hline 3 & $\mathrm{~F}$ & 56 & $\begin{array}{l}\text { Steroids, } \\
\text { splenectomy }\end{array}$ & 1 & No & 98 & 98 & No & $\mathrm{CR}$ \\
\hline 4 & $\mathrm{~F}$ & 42 & $\begin{array}{l}\text { Steroids, } \\
\text { splenectomy, } \\
\text { azathioprine, } \\
\text { vincristine, danazol }\end{array}$ & 2 & Yes & 2 & 98 & $\begin{array}{l}\text { Steroids, azathioprine, } \\
\text { vincristine, } \\
\text { eltrombopag }\end{array}$ & PR \\
\hline 5 & $\mathrm{~F}$ & 58 & $\begin{array}{l}\text { Steroids, } \\
\text { splenectomy, } \\
\text { azathioprine, } \\
\text { vincristine }\end{array}$ & 1 & Yes & 5 & 96 & Steroids & $\mathrm{CR}$ \\
\hline \multicolumn{10}{|c|}{ Late responders to rituximab therapy $(n=2)$} \\
\hline Number & Sex & $\begin{array}{l}\text { Actual } \\
\text { age }\end{array}$ & Previous therapies & $\begin{array}{l}\text { TTR } \\
\text { (weeks) }\end{array}$ & Relapse & $\begin{array}{l}\text { DOR } \\
\text { (months) }\end{array}$ & $\begin{array}{l}\text { FU period } \\
\text { after } \\
\text { first R } \\
\text { therapy } \\
\text { (months) }\end{array}$ & $\begin{array}{l}\text { Treatment } \\
\text { after } \mathrm{R} \text { therapy }\end{array}$ & $\begin{array}{l}\text { ITP final } \\
\text { status }\end{array}$ \\
\hline 1 & $\mathrm{~F}$ & 48 & $\begin{array}{l}\text { Steroids, } \\
\text { splenectomy, } \\
\text { azathioprine, } \\
\text { vincristine, } \\
\text { danazol }\end{array}$ & 8 & Yes & 3 & 96 & Steroids, danazol & $\mathrm{CR}$ \\
\hline 2 & M & 60 & $\begin{array}{l}\text { Steroids, } \\
\text { splenectomy, } \\
\text { azathioprine }\end{array}$ & 12 & Yes & 9 & 96 & Eltrombopag & $\mathrm{PR}$ \\
\hline
\end{tabular}

was $3.6 \pm 1.04$. The mean duration of follow-up after rituximab was $89.7 \pm 19.4$ months. Seven of the patients (46.7\%) showed an initial response ( $5 \mathrm{ER}$ and $2 \mathrm{LR}$ ). The cumulative response rate was $46.7 \%$. Four of the 15 patients (26.7\%) achieved SR with a duration of more than 6 months. Patients with SR included 3 early responders and 1 late responder. During follow-up, 2 of the patients who obtained SR lost their response 9 months and 52 months after the initiation of rituximab, respectively. Durations of ER and LR were $51 \pm 47.2$ months and $6 \pm 4.2$ months, respectively. The duration of $\mathrm{OR}(\mathrm{ER}+\mathrm{LR})$ was $38.1 \pm 44.4$ months. One patient succumbed to intracranial hemorrhage and another to myocardial infarction. Patient characteristics of early and late responders are summarized in Table 2.

\section{Comparison of Immune Thrombocytopenia Patients According to Their Response Status to Rituximab Therapy}

Clinical and laboratory features of ITP patients stratified by response status to rituximab are outlined in Table 3 . The presence of comorbid diseases was more frequent in non-responders compared to responders, but the difference was not statistically significant (62.5\% and $14.3 \%$, respectively, $p=0.117)$.

The presence of response did not correlate with actual age, age at diagnosis, age at time of splenectomy, age at initiation of rituximab, sex, hemoglobin level and platelet count at diagnosis, initial response to corticosteroids, number of previous therapies, interval between diagnosis and initiation of rituximab, and time between splenectomy and rituximab therapy $(r<0.2)$. A weak positive correlation was detected between the presence of response and the interval between diagnosis and splenectomy $(r=0.281)$. A moderate positive correlation was found between the presence of response and WBC count at diagnosis $(r=0.464)$. We showed a moderate inverse correlation between the presence of response and comorbid diseases ( $r=-0.423)$.

\section{Clinical Course}

Of the 7 patients with response to rituximab, 5 (3 in ER and 2 in LR) relapsed after a response duration ranging from 2 to 


\begin{tabular}{|c|c|c|c|}
\hline Chronic refractory ITP patients & $\begin{array}{l}\text { Patients with OR, } n=7 \\
\text { (Mean } \pm \text { SD) }\end{array}$ & $\begin{array}{l}\text { Patients with NR, } n=8 \\
\text { (Mean } \pm \text { SD) }\end{array}$ & p \\
\hline Age, at diagnosis, years & $26.1 \pm 13.9$ & $32.7 \pm 17.7$ & 0.602 \\
\hline Actual age, years & $51 \pm 8.8$ & $56.7 \pm 13.6$ & 0.685 \\
\hline Age at the time of splenectomy, years & $28.7 \pm 13.5$ & $34.3 \pm 18.4$ & 0.817 \\
\hline Female, n (\%) & $6(85.7 \%)$ & $7(87.5 \%)$ & 1 \\
\hline Hemoglobin at diagnosis, $\mathrm{g} / \mathrm{dL}$ & $11.4 \pm 0.9$ & $11 \pm 1$ & 0.363 \\
\hline WBC count at diagnosis, $/ \mathrm{mm}^{3}$ & $9514 \pm 2150$ & $7637 \pm 1837$ & 0.083 \\
\hline Platelet count at diagnosis, $/ \mathrm{mm}^{3}$ & $10,428 \pm 4613$ & $9812 \pm 4208$ & 0.861 \\
\hline Time from splenectomy to rituximab therapy, months & $187.8 \pm 130$ & $171.2 \pm 82.8$ & 0.728 \\
\hline Presence of accessory spleen before rituximab, $\mathrm{n}(\%)$ & $2(28.6 \%)$ & $3(37.5 \%)$ & 1 \\
\hline $\begin{array}{l}\text { Response to initial corticosteroids, } n(\%) \\
R(n, \%) \\
\text { NR }(n, \%)\end{array}$ & $\begin{array}{l}7(100 \%) \\
3(42.9 \%) \\
4(57.1 \%)\end{array}$ & $\begin{array}{l}8(100 \%) \\
5(62.5 \%) \\
3(37.5 \%)\end{array}$ & $\begin{array}{l}0.619 \\
- \\
-\end{array}$ \\
\hline $\begin{array}{l}\text { Accompanying diseases, } n(\%) \\
\text { Hypertension }(n, \%) \\
\text { Diabetes mellitus }(n, \%)\end{array}$ & $\begin{array}{l}1(14.3 \%) \\
0 \\
1(14.3 \%)\end{array}$ & $\begin{array}{l}5(62.5 \%) \\
3(37.5 \%) \\
2(25 \%)\end{array}$ & $\begin{array}{l}0.117 \\
- \\
-\end{array}$ \\
\hline Follow-up period after rituximab treatment, $\mathrm{m}$ & $97.1 \pm 30.1$ & $83.2 \pm 25.4$ & 0.282 \\
\hline
\end{tabular}

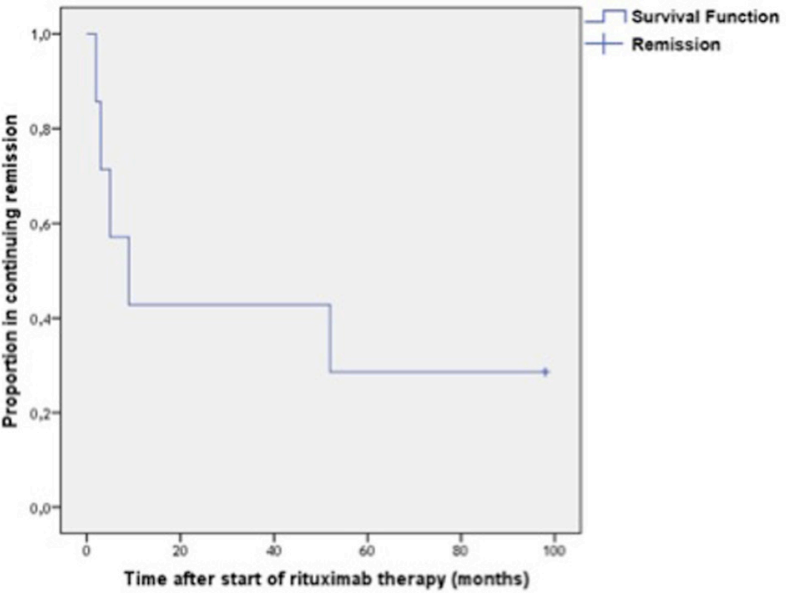

Figure 1. Proportion of patients with ongoing response during long-term follow-up. Two of the 7 patients (28.6\%) still maintained their response 98 months after initiation of rituximab.

52 months (Figure 1). Figure 2 demonstrates the mean platelet counts in the whole population after initiation of rituximab. The mean platelet counts showed a trend to be higher in initial rituximab responders $(n=7)$ compared to non-responders $(n=8)$ $\left(112,201 \pm 29,008 / \mathrm{mm}^{3}\right.$ vs. $33,750 \pm 31,332 / \mathrm{mm}^{3}, \mathrm{p}=0.060$, odds ratio: $7.8 ; 95 \% \mathrm{Cl} 35,212-176,049)$ (Figure 3).

\section{Status of Patients at the Final Observation}

Seven of the 15 patients (46.7\%) showed an initial response (5 ER and 2 LR). However, 3 of the 5 early responders (20\%) and all of the late responders lost their response, leaving 2 patients

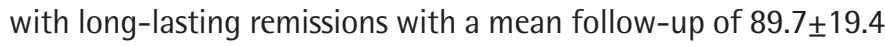
months. Relapsed patients and patients with NR subsequently received various types of treatment, including steroids $(n=12)$, eltrombopag $(n=4)$, azathioprine $(n=2)$, vincristine $(n=1)$, danazol $(n=1)$, IVIG $(n=1)$, and accessory spleen operation $(n=1)$. All of the initial 7 responders to rituximab achieved long-term remission even after relapse (5 CR, 2 PR), irrespective of subsequent treatment modalities (4: steroids, 2: eltrombopag, 1: azathioprine, 1: vincristine, 1: danazol, 1: IVIG) (Figure 4). In contrast, of the 8 non-responders, 2 patients still showed NR and 2 died (1 of intracranial hemorrhage and 1 of myocardial infarction). In total, 11 of the 15 patients (73.3\%) achieved CR or PR during long-term observation with a mean follow-up time of $89.7 \pm 19.4$ months.

\section{Discussion}

The algorithm for managing adult ITP has changed with the advent of rituximab and TPO-receptor agonists as options 


\begin{tabular}{|c|c|c|c|c|c|c|c|c|c|c|c|}
\hline & 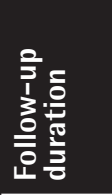 & & I & 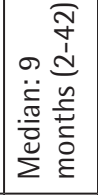 & 1 & 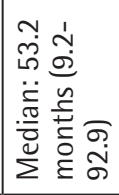 & 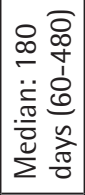 & 1 & 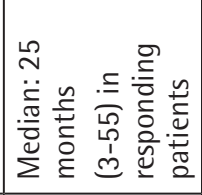 & 1 & 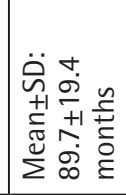 \\
\hline & 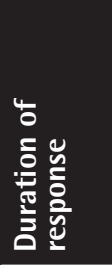 & & 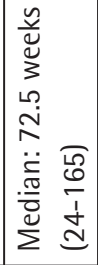 & . & 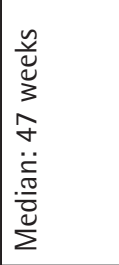 & & 1 & 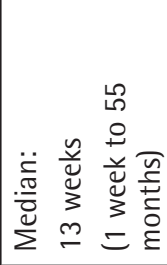 & I & 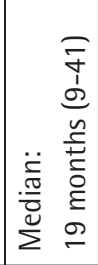 & 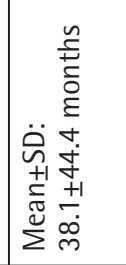 \\
\hline فํ. & 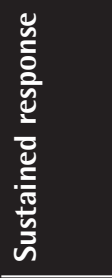 & 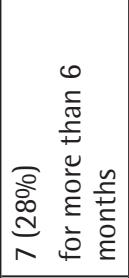 & 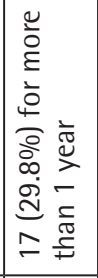 & 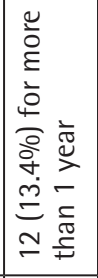 & 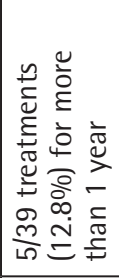 & 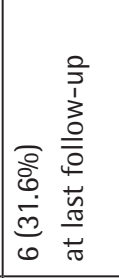 & 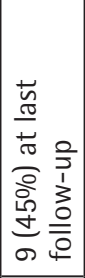 & 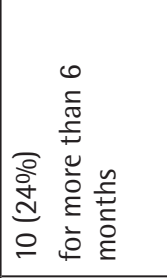 & 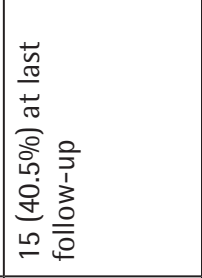 & 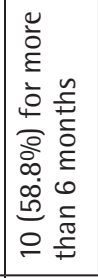 & 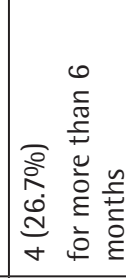 \\
\hline 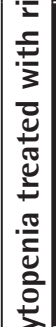 & 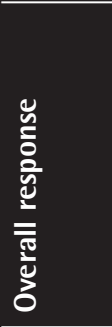 & $\begin{array}{l}\overline{\mathrm{o}} \\
\text { స్త్ర } \\
\underline{m}\end{array}$ & $\begin{array}{l}\overline{\bar{a}} \\
\frac{\partial}{6} \\
\bar{m} \\
\bar{m}\end{array}$ & 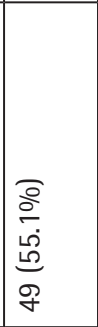 & 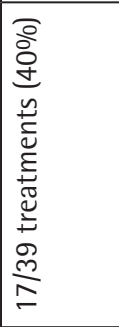 & & 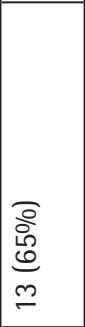 & 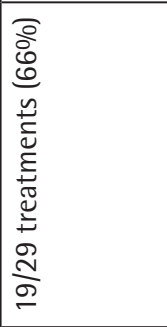 & 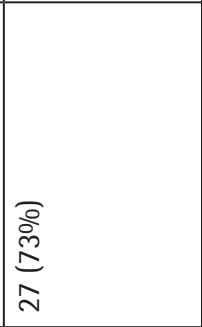 & 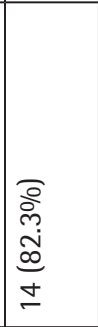 & 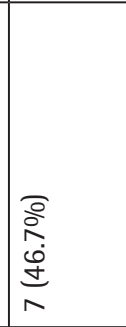 \\
\hline 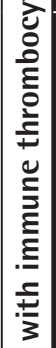 & 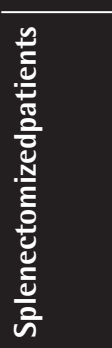 & 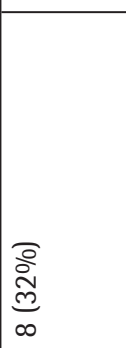 & 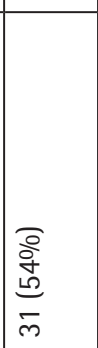 & 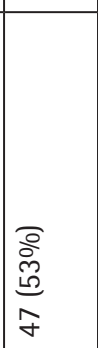 & 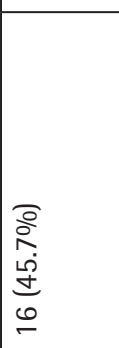 & $\begin{array}{l}\text { o } \\
\text { in } \\
\stackrel{0}{0} \\
\text { N }\end{array}$ & 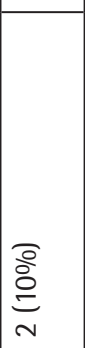 & 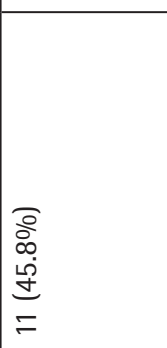 & 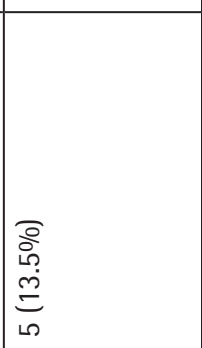 & 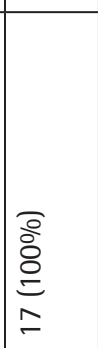 & 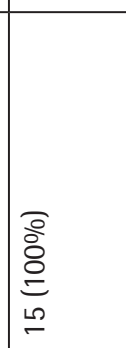 \\
\hline 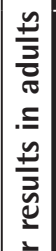 & 产 & 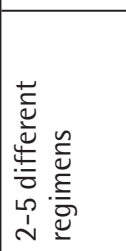 & 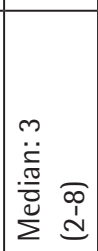 & 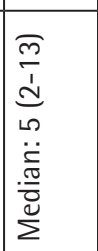 & 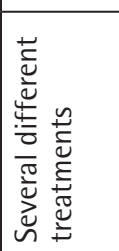 & 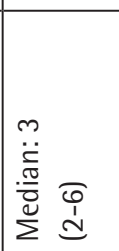 & 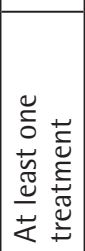 & 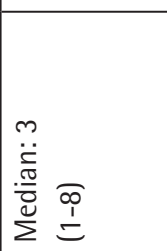 & 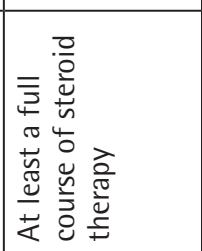 & 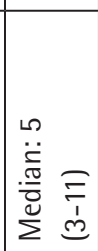 & 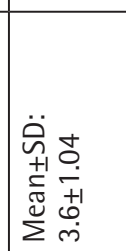 \\
\hline 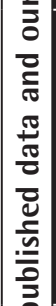 & 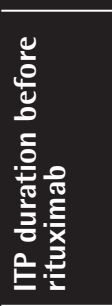 & 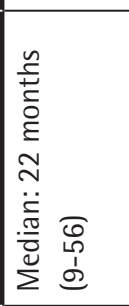 & 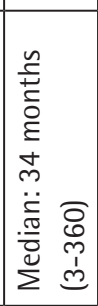 & 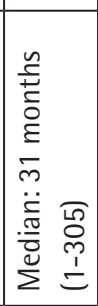 & 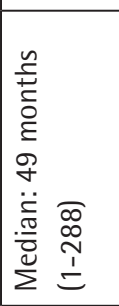 & 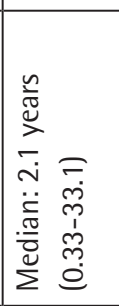 & I & I & 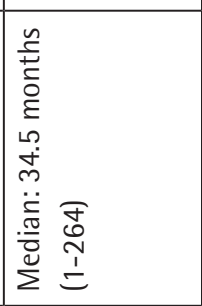 & 1 & 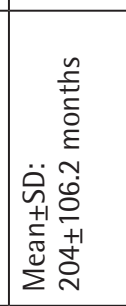 \\
\hline 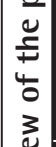 & 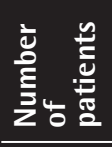 & $\stackrel{\sim}{\sim}$ & in & $\infty$ & $\stackrel{\llcorner}{m}$ & 9 & ㅇ & $\stackrel{\sim}{\sim}$ & $\hat{m}$ & $\approx$ & $\stackrel{2}{\sim}$ \\
\hline 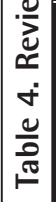 & $\stackrel{4}{\dddot{\Psi}}$ & 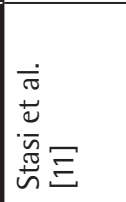 & 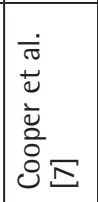 & 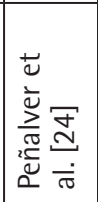 & 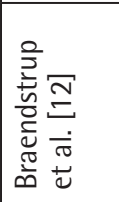 & 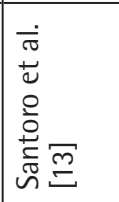 & 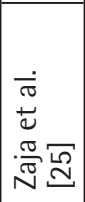 & 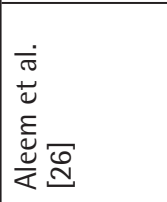 & 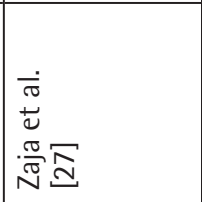 & 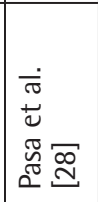 & 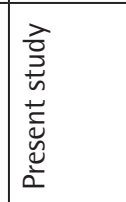 \\
\hline
\end{tabular}




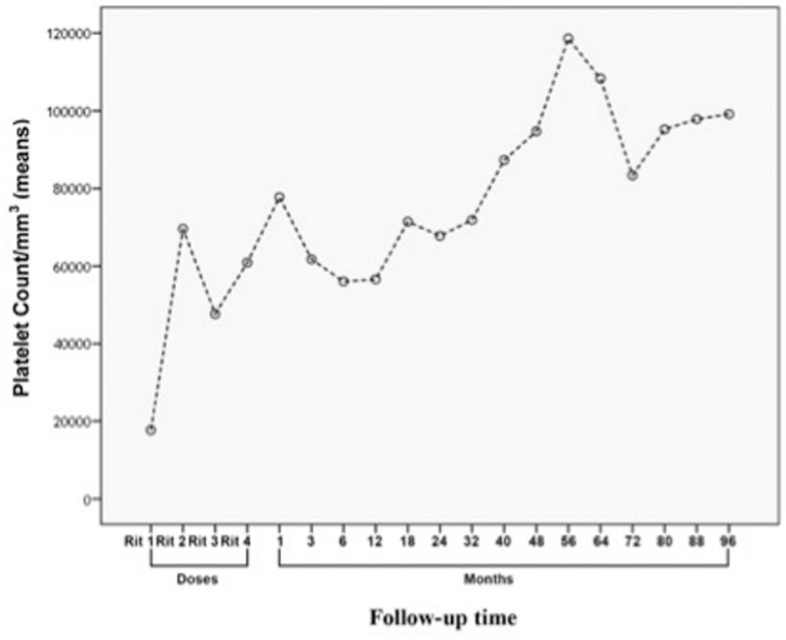

Figure 2. Mean platelet counts in the whole study group after initiation of rituximab. Relapsed patients and non-responders were treated with various other therapies. Mean platelet counts at times of first, second, third, and fourth doses of rituximab and $1^{\text {st }}, 3^{\text {rd }}, 6^{\text {th }}, 12^{\text {th }}$, $18^{\text {th }}, 24^{\text {th }}, 32^{\text {to }}, 40^{\text {th }}, 48^{\text {th }}, 56^{\text {th }}, 64^{\text {th }}, 72^{\text {td }}, 80^{\text {th }}, 88^{\text {th }}$, and $96^{\text {th }}$ months of rituximab $( \pm S D)$ were $17,400 \pm 8878 / \mathrm{mm}^{3}, 70,666 \pm 122,495 / \mathrm{mm}^{3}$, $42,266 \pm 53,518 / \mathrm{mm}^{3}, \quad 53,533 \pm 79,974 / \mathrm{mm}^{3}, \quad 68,733 \pm 95,213 / \mathrm{mm}^{3}$, $54,333 \pm 81,260 / \mathrm{mm}^{3}, \quad 50,400 \pm 85,816 / \mathrm{mm}^{3}, \quad 50,266 \pm 79,408 / \mathrm{mm}^{3}$, $62,666 \pm 110,205 / \mathrm{mm}^{3}, 59,880 \pm 116,443 / \mathrm{mm}^{3}, 62,920 \pm 103,727 / \mathrm{mm}^{3}$, $76,746 \pm 101,374 / \mathrm{mm}^{3}, \quad 94,707 \pm 103,763 / \mathrm{mm}^{3}, \quad 118,607 \pm 128,846 /$ $\mathrm{mm}^{3}, 108,315 \pm 119,597 / \mathrm{mm}^{3}, 83,384 \pm 107,987 / \mathrm{mm}^{3}, 95,230 \pm 104,396 /$ $\mathrm{mm}^{3}, 97,846 \pm 98,858 / \mathrm{mm}^{3}$, and $99,153 \pm 99,049 / \mathrm{mm}^{3}$, respectively.

for second-line treatment. The lack of studies comparing splenectomy to other second-line therapy options presents an important dilemma. Rituximab may be a curative therapy with an initial response in 50\%-60\% of ITP patients and a SR of 3-5 years in $20 \%$ of patients [23]. The primary aim of our study was to evaluate the long-term efficacy of rituximab treatment in 15 patients with chronic refractory ITP. The patients described in this study had persistent, severe ITP and had received a mean of $3.6 \pm 1.04$ previous therapies.

Table 4 summarizes our results as well the results of previous studies describing adult ITP patients treated with rituximab. Seven of our 15 patients achieved an initial response to rituximab (46.7\%) (5 ER and 2 LR). Various studies have used different criteria to define response to ITP treatment. Our results are comparable with those of several studies that reported response rates between $40 \%$ and 55.1\% [7,11,12,13,24]. However, our results are less favorable compared to several other reports $[6,25,26,27,28]$. In the systematic review by Arnold et al., the overall platelet count response to rituximab was $62.5 \%$ in adult ITP patients [6]. Zaja et al. in 2 different studies reported an initial response rate of $65 \%$ (13/20 patients) and 73\% (27/37 patients), respectively $[25,27]$. The latter study hypothesized that earlier administration of rituximab enables higher rates of long-lasting response in adult ITP [27]. Moreover, our results are inferior to those of other studies reporting an OR of $66 \%$ and $82.3 \%$, respectively $[26,28]$.

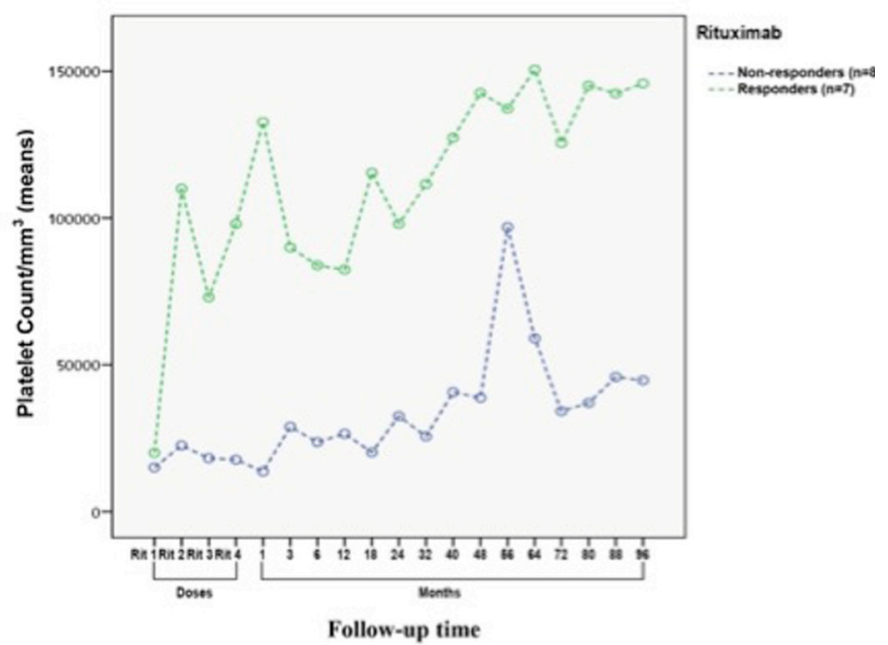

Figure 3. Comparison of mean platelet counts in responders and non-responders following rituximab therapy. There was a trend towards higher mean platelet counts $( \pm S D)$ in initial rituximab responders $(n=7)$ compared to non-responders $(n=8)$ $\left(112,201 \pm 29,008 / \mathrm{mm}^{3}\right.$ vs. $33,750 \pm 31,332 / \mathrm{mm}^{3}, \quad p=0.06$, odds ratio: $7.8 ; 95 \% \mathrm{Cl} 35,212-176,049)$. In rituximab responders mean platelet counts at times of first, second, third, and fourth doses of rituximab and $1^{\text {st }}, 3^{\text {rd }}, 6^{\text {th }}, 12^{\text {th }}, 18^{\text {th }}, 24^{\text {th }}, 32^{\text {td }}, 40^{\text {th }}, 48^{\text {th }}, 56^{\text {th }}$, $64^{\text {th }}, 72^{\text {nd }}, 80^{\text {th }}, 88^{\text {th }}$, and $96^{\text {th }}$ months of rituximab $( \pm S D)$ were $20,000 \pm 2905 / \mathrm{mm}^{3}, 110,000 \pm 47,594 / \mathrm{mm}^{3}, 73,000 \pm 18,886 / \mathrm{mm}^{3}$, $98,000 \pm 28,684 / \mathrm{mm}^{3}, 132,714 \pm 30,811 / \mathrm{mm}^{3}, 90,000 \pm 31,195 / \mathrm{mm}^{3}$, $83,857 \pm 33,795 / \mathrm{mm}^{3}, 82,428 \pm 31,051 / \mathrm{mm} 3,115,428 \pm 41,586 / \mathrm{mm}^{3}$, $98,028 \pm 46,959 / \mathrm{mm}^{3}, \quad 111,571 \pm 39,294 / \mathrm{mm}^{3}, \quad 127,342 \pm 37,568 /$ $\mathrm{mm}^{3}, \quad 142,657 \pm 35,001 / \mathrm{mm}^{3}, \quad 137,228 \pm 50,189 / \mathrm{mm}^{3}$, $150,571 \pm 43,329 / \mathrm{mm}^{3}, \quad 125,571 \pm 38,298 / \mathrm{mm}^{3}, \quad 145,142 \pm 34,753 /$ $\mathrm{mm}^{3}, \quad 142,428 \pm 33,638 / \mathrm{mm}^{3}$, and $145,857 \pm 33,156 / \mathrm{mm}^{3}$, respectively. In non-responders mean platelet counts at times of first, second, third, and fourth doses of rituximab and $1^{\text {st }}$, $3^{\text {rd }}, 6^{\text {th }}, 12^{\text {th }}, 18^{\text {th }}, 24^{\text {th }}, 32^{\text {td }}, 40^{\text {th }}, 48^{\text {th }}, 56^{\text {th }}, 64^{\text {th }}, 72^{\text {td }}, 80^{\text {th }}, 88^{\text {th }}$, and $96^{\text {th }}$ months of rituximab $\left( \pm\right.$ SD) were $15,000 \pm 3138 / \mathrm{mm}^{3}$, $22,500 \pm 51,407 / \mathrm{mm}^{3}, 18,166 \pm 20,399 / \mathrm{mm}^{3}, 17,666 \pm 30,983 / \mathrm{mm}^{3}$, $13,666 \pm 33,279 / \mathrm{mm}^{3}, 28,833 \pm 33,695 / \mathrm{mm}^{3}, 23,666 \pm 36,502 / \mathrm{mm}^{3}$, $26,500 \pm 33,539 / \mathrm{mm}^{3}, 20,166 \pm 44,918 / \mathrm{mm}^{3}, 32,500 \pm 50,722 / \mathrm{mm}^{3}$, $25,633 \pm 42,442 / \mathrm{mm}^{3}, 40,633 \pm 40,578 / \mathrm{mm}^{3}, 38,766 \pm 37,805 / \mathrm{mm}^{3}$, $96,883 \pm 54,210 / \mathrm{mm}^{3}, 59,016 \pm 46,800 / \mathrm{mm}^{3}, 34,166 \pm 41,367 / \mathrm{mm}^{3}$, $37,000 \pm 37,537 / \mathrm{mm}^{3}, 45,833 \pm 36,334 / \mathrm{mm}^{3}$, and $44,666 \pm 35,812 /$ $\mathrm{mm}^{3}$, respectively.

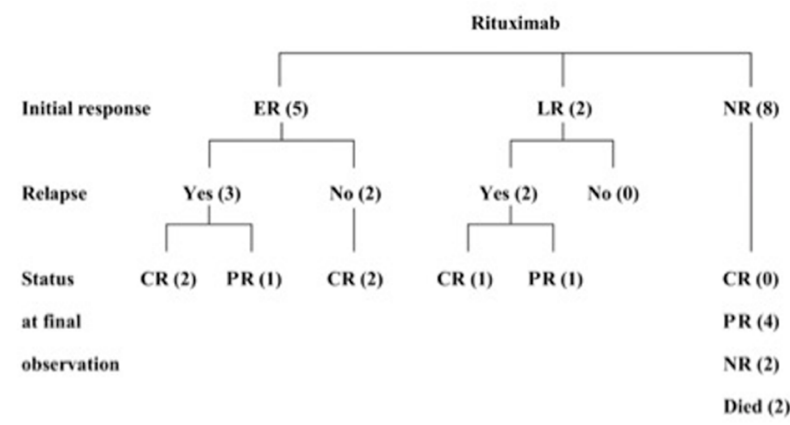

Figure 4. Algorithm of long-term outcome of 15 adults with immune thrombocytopenia after treatment with rituximab. ER, $L R, C R, P R$, and NR denote early response, late response, complete response, partial response, and no response, respectively. 
The strength of our study lies in the long follow-up period of our patients with a mean duration of $89.7 \pm 19.4$ months. We showed that 5 of the 7 responding patients $(71.4 \%)(3 / 5 E R, 2 / 2$ LR) relapsed after 2, 3, 5, 9, and 52 months, respectively. Four relapses occurred within 1 year after initial response. These findings are largely in line with previous data $[9,29]$. Patel et al. reported late relapses 2 years after the initiation of rituximab in adults and suggested that regular follow-up at 3-month intervals is indicated at least for the first 5 years in adults [20]. In our study, 2 adult patients showed continued response after 98 months and 1 patient relapsed 52 months after initiation of rituximab. A higher relapse rate occurred among our patients with LR compared to those with ER (100\% vs. 60\%). However, due to the small size of our study population, patients with ER and LR could not be compared. This issue will be the subject of our further studies.

We evaluated the relationship between clinical and laboratory variables and response to rituximab. Our results are in line with findings of several studies, which reported that splenectomy, age, sex, number of previous treatments, and pretreatment platelet count were not associated with response to rituximab $[7,12]$. In line with the study by Santoro et al., we demonstrated that the time between diagnosis and the start of rituximab therapy did not correlate with response to rituximab [13]. Further studies are needed to determine the best scheduling of rituximab in the course of ITP.

Considering the entire population, the SR rate in our study was $26.7 \%$ (4/15 patients) with a duration over 6 months and a mean follow-up of $89.7 \pm 19.4$ months. The disease-free survival of these 4 patients at 98 months was $50 \%$. Several other authors reported SR rates ranging from 28\% to $40.5 \%$ $[7,11,13,19,27]$. Garcia-Chaves et al. reported a SR rate of $67 \%$ over a duration of 6 months, a finding superior to our results [30]. In that study, the mean number of therapies was 5.5 and $83 \%$ of patients had failed to respond to splenectomy [30]. In the pilot study by Arnold et al., the OR rate to rituximab at 6 months in non-splenectomized adults with newly diagnosed or relapsed primary ITP was 62.5\% [31]. The aforementioned study is crucial in evaluating whether rituximab could be a valuable therapeutic alternative to splenectomy [31]. Godeau et al. evaluated the efficacy of rituximab in adult chronic ITP patients who had received at least 1 previous therapy and were potential candidates for splenectomy and reported that at 2 years the response rate was 40\% [19]. Patel et al., in their study on long-term outcome after initiation of rituximab, reported that 21\% of adults maintained response for at least 5 years [20]. Expert consensuses reported that 80\% of ITP patients respond to splenectomy, and the response is sustained in approximately two-thirds of patients over 5-10 years [10,32]. Taking into account our results and literature review on efficacy and longlasting response rate, we think that rituximab treatment has a role in a subset of chronic ITP patients.

\section{Conclusion}

To conclude, in 15 chronic refractory ITP patients, we showed an initial response rate and SR of $46.7 \%$ and $26.7 \%$, respectively, while $71.4 \%$ of responders subsequently relapsed in a mean follow-up period of 89.7 months. The continuing effect of rituximab had declined to $13.3 \%$ (2/15 patients) at the last followup. Of importance in clinical practice is the observation that all initial responders to rituximab achieved long-lasting remission even after relapse, independent of subsequent therapies. Over a very long period of immunosuppression, we did not record any serious adverse events. In the era of TPO-receptor agonists, we think that rituximab still has a role in the treatment of chronic refractory ITP. Our data, based on a long period of observation, confirm the efficacy of rituximab in refractory primary ITP. Future randomized studies including large case series are needed to determine the optimal role of rituximab and which subgroup of ITP patients can most benefit from this therapy.

\section{Ethics}

Ethics Committee Approval: Rituximab was offered to these patients as an off-label treatment following the approval of the Ministry of Health; Informed Consent: Informed consent for study participation was obtained from all patients.

\section{Authorship Contributions}

Research Design: Fehmi Hindilerden, İpek Yönal-Hindilerden, Meliha Nalçacl, Reyhan Diz-Küçükkaya; Concept: Fehmi Hindilerden, Mustafa Nuri Yenerel, Reyhan Diz-Küçükkaya; Data Collection or Processing: Fehmi Hindilerden, İpek YönalHindilerden; Analysis or Interpretation: Fehmi Hindilerden; Literature Search: Fehmi Hindilerden, İpek Yönal-Hindilerden; Writing: Fehmi Hindilerden, İpek Yönal-Hindilerden, Mustafa NuriYenerel, Meliha Nalçacı, Reyhan Diz-Küçükkaya.

Conflict of Interest: The authors of this paper have no conflicts of interest, including specific financial interests, relationships, and/or affiliations relevant to the subject matter or materials included.

\section{References}

1. Rodeghiero F, Stasi R, Gernsheimer T, Michel M, Provan D, Arnold DM, Bussel JB, Cines DB, Chong BH, Cooper N, Godeau B, Lechner K, Mazzucconi MG, McMillan R, Sanz MA, Imbach P, Blanchette V, Kühne T, Ruggeri M, George $J N$. Standardization of terminology, definitions and outcome criteria in immune thrombocytopenic purpura of adults and children: report from an international working group. Blood 2009;113:2386-2393.

2. Godeau B, Stasi R. Is B-cell depletion still a good strategy for treating immune thrombocytopenia? Presse Med 2014;43:e79-85.

3. George JN, Woolf SH, Raskob GE, Wasser JS, Aledort LM, Ballem PJ, Blanchette VS, Bussel JB, Cines DB, Kelton JG, Lichtin AE, McMillan R, Okerbloom JA, Regan $\mathrm{DH}$, Warrier I. Idiopathic thrombocytopenic purpura: a practice guideline developed by explicit methods for the American Society of Hematology. Blood 1996;88:3-40. 
4. Kojouri K, Vesely SK, Terrell DR, George JN. Splenectomy for adult patients with idiopathic thrombocytopenic purpura: a systematic review to assess long-term platelet count responses, prediction of response, and surgical complications. Blood 2004;104:2623-2634.

5. George JN. Management of patients with refractory immune thrombocytopenic purpura. J Thromb Haemost 2006;4:1664-1672.

6. Arnold DM, Dentali F, Crowther MA, Meyer RM, Cook RJ, Sigouin C, Fraser GA, Lim W, Kelton JG. Systematic review: efficacy and safety of rituximab for adults with idiopathic thrombocytopenic purpura. Ann Intern Med 2007;146:25-33.

7. Cooper N, Stasi R, Cunningham-Rundles S, Feuerstein MA, Leonard JP, Amadori S, Bussel JB. The efficacy and safety of B-cell depletion with antiCD20 monoclonal antibody in adults with chronic immune thrombocytopenic purpura. Br J Haematol 2004;125:232-239.

8. Zaja $F$, lacona I, Masolini P, Russo D, Sperotto A, Prosdocimo S, Patriarca $F$, de Vita $S$, Regazzi M, Baccarani M, Fanin R. B-cell depletion with rituximab as treatment for immune hemolytic anemia and chronic thrombocytopenia. Haematologica 2002;87:189-195.

9. Bennett $C M$, Rogers ZR, Kinnamon DD, Bussel JB, Mahoney DH, Abshire TC, Sawaf $H$, Moore TB, Loh ML, Glader BE, McCarthy MC, Mueller BU, Olson TA, Lorenzana AN, Mentzer WC, Buchanan GR, Feldman HA, Neufeld EJ. Prospective phase $1 / 2$ study of rituximab in childhood and adolescent chronic immune thrombocytopenic purpura. Blood 2006;107:2639-2642.

10. Provan $D$, Stasi $R$, Newland $A C$, Blanchette VS, Bolton-Maggs $P$, Bussel JB, Chong BH, Cines DB, Gernsheimer TB, Godeau B, Grainger J, Greer I, Hunt BJ, Imbach PA, Lyons G, McMillan R, Rodeghiero F, Sanz MA, Tarantino M, Watson $S$, Young J, Kuter DJ. International consensus report on the investigation and management of primary immune thrombocytopenia. Blood 2010;115:168-186.

11. Stasi R, Pagano A, Stipa E, Amadori S. Rituximab chimeric anti-CD20 monoclonal antibody treatment for adults with chronic idiopathic thrombocytopenic purpura. Blood 2001;98:952-957.

12. Braendstrup P, Bjerrum OW, Nielsen OJ, Jensen BA, Clausen NT, Hansen PB, Andersen I, Schmidt K, Andersen TM, Peterslund NA, Birgens HS, Plesner T, Pedersen BB, Hasselbalch HC. Rituximab chimeric anti-CD20 monoclonal antibody treatment for adult refractory idiopathic thrombocytopenic purpura. Am J Hematol 2005;78:275-280.

13. Santoro C, Biondo F, Baldacci E, De Propris MS, Guarini A, Paoloni F, Foà $R$, Mazzucconi MG. Rituximab in previously treated primary immune thrombocytopenia patients: evaluation of short- and long-term efficacy and safety. Acta Haematol 2014;132:24-29.

14. Schweizer $C$, Reu FJ, Ho AD, Hensel M. Low rate of long-lasting remissions after successful treatment of immune thrombocytopenic purpura with rituximab. Ann Hematol 2007;86:711-717.

15. Al-Habsi K, Al-Khabori M, Al-Muslahi M, Pathare A, Al-Farsi K, Al-Huneini M, Al-Lamki S, Al-Kindi S. Rituximab leads to long remissions in patients with chronic immune thrombocytopenia. Oman Med J 2015;30:111-114.

16. Chugh S, Darvish-Kazem S, Lim W, Crowther MA, Ghanima W, Wang G, Heddle NM, Kelton JG, Arnold DM. Rituximab plus standard of care for treatment of primary immune thrombocytopenia: a systematic review and meta-analysis. Lancet Haematol 2015;2:e75-81.

17. Khellaf $M$, Charles-Nelson A, Fain 0 , Terriou L, Viallard JF, Cheze $S$, Graveleau J, Slama B, Audia S, Ebbo M, Le Guenno G, Cliquennois M, Salles G, Bonmati C, Teillet $F$, Galicier L, Hot A, Lambotte 0 , Lefrère $F$, Sacko $S$, Kengue DK, Bierling $P$, Roudot-Thoraval F, Michel M, Godeau B. Safety and efficacy of rituximab in adult immune thrombocytopenia: results from a prospective registry including 248 patients. Blood 2014;124:3228-3236.

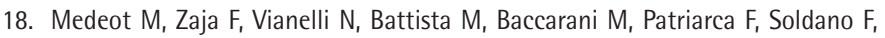
Isola $M$, De Luca $S$, Fanin R. Rituximab therapy in adult patients with relapsed or refractory immune thrombocytopenic purpura: long-term follow-up results. Eur J Haematol 2008;81:165-169.

19. Godeau B, Porcher R, Fain $O$, Lefrère F, Fenaux $P$, Cheze $S$, Vekhoff $A$, Chauveheid

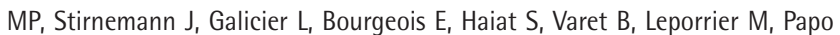
$T$, Khellaf $M$, Michel $M$, Bierling P. Rituximab efficacy and safety in adult splenectomy candidates with chronic immune thrombocytopenic purpuvra: results of a prospective multicenter phase 2 study. Blood 2008;112:999-1004.
20. Patel VL, Mahévas M, Lee SY, Stasi $R$, Cunningham-Rundles $S$, Godeau B, Kanter J, Neufeld E, Taube T, Ramenghi U, Shenoy S, Ward MJ, Mihatov N, Patel VL, Bierling $\mathrm{P}$, Lesser $\mathrm{M}$, Cooper $\mathrm{N}$, Bussel JB. Outcomes 5 years after response to rituximab therapy in children and adults with immune thrombocytopenia. Blood 2012;119:5989-5995.

21. Zaja F, Volpetti $S$, Chiozzotto M, Puglisi $S$, Isola M, Buttignol S, Fanin R. Longterm follow-up analysis after rituximab salvage therapy in adult patients with immune thrombocytopenia. Am J Hematol 2012;87:886-889.

22. Gudbrandsdottir $S$, Birgens HS, Frederiksen $H$, Jensen $B A$, Jensen $M K$, Kjeldsen L, Klausen TW, Larsen H, Mourits-Andersen HT, Nielsen CH, Nielsen OJ, Plesner T, Pulczynski S, Rasmussen IH, Rønnov-Jessen D, Hasselbalch HC. Rituximab and dexamethasone vs dexamethasone monotherapy in newly diagnosed patients with primary immune thrombocytopenia. Blood 2013;121:1976-1981.

23. Ghanima W, Godeau B, Cines DB, Bussel JB. How I treat immune thrombocytopenia: the choice between splenectomy or a medical therapy as a second-line treatment. Blood 2012;120:960-969.

24. Peñalver $F J$, Jiménez-Yuste $V$, Almagro $M$, Alvarez-Larrán $A$, Rodríguez $L$, Casado M, Gallur L, Giraldo P, Hernández R, Menor D, Rodríguez MJ, Caballero D, González R, Mayans J, Millán I, Cabrera JR; Multi-institutional Retrospective Spanish Study Group on the Use of Rituximab in Refractory ITP. Rituximab in the management of chronic immune thrombocytopenic purpura: an effective and safe therapeutic alternative in refractory patients. Ann Hematol 2006;85:400406.

25. Zaja $F$, Vianelli N, Sperotto A, De Vita $S$, lacona I, Zaccaria A, Masolini $P$, Tomadini V, Tani M, Molinari AL, Baccarani M, Fanin R. B-cell compartment as the selective target for the treatment of immune thrombocytopenias. Haematologica 2003;88:538-546.

26. Aleem $A$, Alaskar AS, Algahtani $F$, Rather M, Almahayni MH, Al-Momen A. Rituximab in immune thrombocytopenia: transient responses, low rate of sustained remissions and poor response to further therapy in refractory patients. Int J Hematol 2010;92:283-288.

27. Zaja F, Vianelli N, Battista M, Sperotto A, Patriarca F, Tomadini V, Fili C, Tani M, Baccarani $M$, Fanin R. Earlier administration of rituximab allows higher rate of long-lasting response in adult patients with autoimmune thrombocytopenia. Exp Hematol 2006;34:571-572.

28. Pasa $\mathrm{S}$, Altintas A, Cil T, Danis R, Ayyildiz 0. The efficacy of rituximab in patients with splenectomized refractory chronic idiopathic thrombocythopenic purpura. J Thromb Thrombolysis 2009;27:329-333.

29. Mueller BU, Bennett CM, Feldman HA, Bussel JB, Abshire TC, Moore TB, Sawaf $H$, Loh ML, Rogers ZR, Glader BE, McCarthy MC, Mahoney DH, Olson TA, Feig SA, Lorenzana AN, Mentzer WC, Buchanan GR, Neufeld EJ; Pediatric Rituximab/ ITP Study Group; Glaser Pediatric Research Network. One year follow-up of children and adolescents with chronic immune thrombocytopenic purpura (ITP) treated with rituximab. Pediatr Blood Cancer 2009;52:259-262.

30. Garcia-Chavez J, Majluf-Cruz A, Montiel-Cervantes L, Esparza MG, Vela-0jeda J; Mexican Hematology Study Group. Rituximab therapy for chronic and refractory immune thrombocytopenic purpura: a long-term follow-up analysis. Ann Hematol 2007;86:871-877.

31. Arnold DM, Heddle NM, Carruthers J, Cook DJ, Crowther MA, Meyer RM, Liu Y, Cook RJ, McLeod A, MacEachern JA, Mangel J, Anderson D, Vickars L, Tinmouth $A$, Schuh AC, Kelton JG. A pilot randomized trial of adjuvant rituximab or placebo for nonsplenectomized patients with immune thrombocytopenia. Blood 2012;119:1356-1362.

32. Neunert C, Lim W, Crowther M, Cohen A, Solberg L Jr, Crowther MA; American Society of Hematology. The American Society of Hematology 2011 evidencebased practice guideline for immune thrombocytopenia. Blood 2011;117:41904207. 